\title{
Sus sp. DNA Encoding cyt $b$ Gene Detection Test on Meat Grinding Samples Using Conventional PCR
}

\author{
Miftahul Lathif Adzakiyyi ${ }^{1}$, Tri Susilowati ${ }^{1}$, Saiku Rokhim ${ }^{1}$, Yuanita Rachmawati ${ }^{2 *}$ \\ ${ }^{1}$ Department of Biology, Faculty of Science and Technology, UIN Sunan Ampel Surabaya \\ ${ }^{2}$ Department of Science Education, Faculty of Tarbiyah, UIN Sunan Ampel Surabaya \\ Jl. Ahmad Yani No.117, Jemur Wonosari, Wonocolo, Surabaya, Jawa Timur 60237, Indonesia \\ e-mail:_miftahullatif@gmail.com ${ }^{1}$,trisusilowati.bio@gmail.com ${ }^{l}, \underline{\text { saiku_rokhim_avicenna@yahoo.com }}{ }^{l}$, \\ yuanitarhartono@gmail.com*2
}

*Correspondent Author

\begin{abstract}
Micro-entrepreneurs with basic ingredients of processed meat such as meatball who do not have a meat grinder, generally using meat grinder at the public market. The problem that occurs is that there is no clear regulation from the Government regarding the guarantee of the halal meat grinding in the Regional Company. This needs to be enhanced as a study, considering that the grinding material does not only come from Halal substances. The purpose of this study was to test pig DNA in meat grinding samples at PD Pasar Surya Surabaya City by using the conventional Polymerase Chain Reaction (PCR) method. DNA was isolated from 11 PD Pasar Surya meat grinding samples, then spectrophotometry was performed. Spectrophotometry results showed that all samples have high DNA concentrations. The primer used is the cyt b pig gene encoder. Predenaturation is performed at a temperature of $95^{\circ} \mathrm{C}-5$ minutes, denaturation of $95^{\circ} \mathrm{C}-45$ seconds, annealing $60^{\circ} \mathrm{C}-30$ seconds, extension $72^{\circ} \mathrm{C}-40$ seconds, and post extension $72^{\circ} \mathrm{C}-5$ minutes. The results of $P C R$ analysis were determined by the emergence of DNA bands of \pm 149 bp as markers of pig DNA. The results showed negative on sample or no pig contamination in 11 samples tested. While the pig sample as positive control showed a band of $\pm 149 \mathrm{bp}$. These results prove that at 11 points of the location of meat grinding there is no contamination of pig DNA.
\end{abstract}

Keywords: conventional PCR, Sus sp. cyt b gene, meat grinding

\section{Introduction}

Micro entrepreneurs with basic ingredients such as processed meat who do not have a grinding tool, will decide grind meat to a public meat grinding in the market (Baihaqi, Rachmawati, Rokhim, Munir, \& Hamidah, 2019). Product counterfeiting is a problem that often occurs given the significant increase in profits and to reduce production costs. An example is counterfeiting of meat with farm pigs and wild boars. This is certainly contrary to Islamic religious law adopted by the majority of Indonesian people who state that pigs are forbidden animals to be consumed. According Quran chapter 5 verse 3, Forbidden to you (eat) carcasses, blood, pork, (animal flesh) slaughtered on behalf of other than Allah ... .

Samples of this study are taken from market under supervised by Perusahaan Daerah Pasar Surya (PDPS) of Surabaya City, which is a Regional Market Company of Surabaya engaged in the field of community services in the context of public services, facilities, and infrastructure of traditional markets in Surabaya. Meat grinding in regional markets is often not regulated by National Legal Institution such as The Indonesian Halal Product Guarantee Agency called Badan Penyelenggara Jaminan Produk Halal (BPJPH), which provides guaranteed halal assurance. Nescience of the community whether the meat that is ground by the meat grinding mixed with other haram substances or not, can be a problem.

Polymerase Chain Reaction (PCR) is the most widely studied and widely used technique of nucleic acid amplification. Since it was first proposed by scientists from Cetus Corporation, PCR has developed into a major technique in molecular biology laboratories, including in vitro transcription of PCR templates, recombinant PCR, DNAse I footprinting, sequencing with the help of phage promoters, and so on (Putra, 1997). PCR was first developed in 1985 by Kary B. Mullis (Fatchiyah, Widyarti, \& Rahayu, 2011).

PCR is used to multiply the number of DNA molecules on a particular target by synthesizing new DNA molecules that complement those target DNA molecules through the help of enzymes and oligonucleotides as the 5 primers in a thermocycler. DNA target lengths range from tens to thousands of nucleotides in which the position is enclosed in a pair of primers. Primers that are before the target 
area are called forward primers and those that are after the target area are called reverse primers. The enzyme used as a printer for a newly known set of DNA molecules is called the polymerase enzyme. To be able to print the circuit in PCR technique, dNTPs are also needed which include dATP (nucleotide based on Adenine), dCTP (cytosine), dGTP (guanine), and dTTP (Thymine) (Muladno, 2010). Rachmawati, Rokhim, Munir, \& Agustina (2018) explained that this technology is very possible to ascertain whether a food sample contains pig contaminants, even in small amounts. Yusuf (2010) states that there are three important stages in the PCR process that always repeat in 30-40 cycles and take place quickly, namely Denaturation, Annealing, and Extension.

Cytochrome $\mathrm{b}(c y t b)$ is a gene that is encoded by mitochondrial DNA and is involved in electron transport. The $c y t b$ contains eight helical transmembranes that are connected by the intra membrane or extra membrane domain. The $c y t b$ gene sequence is unique in that there are eternal parts at the species level, so that many researchers have grouped or determined the kinship between animals by using the cyt $b$ gene (Widayanti, Solihin, Sajuthi, \& Perwitasari, 2006). The cyt $b$ gene sequence derived from Sus scrofa has a sequence length of $1140 \mathrm{bp}$. Sus sp. is a species frequently use by human consumption.

The method of analysis using DNA has several advantages, namely DNA can be found in all cell types in an individual with identical genetic information, DNA is a stable molecule in the extraction process, and DNA analysis is very likely to be carried out from several different types of samples (Jain, Brahmbhatt, Rank, Joshi, \& Solanki, 2007; Rachmawati \& Daryono, 2014). Therefore, this study aims to determine the presence of pig DNA content in meat grinding found in Surabaya Solar Market using conventional PCR.

\section{Materials and Methods}

The study was conducted in September-November 2018 at the Integrated Laboratory (Genetics and Tissue Culture) of UIN Sunan Ampel Surabaya. The tools used in this research are mortar, analytical balance, tube, incubator, freezer, vortex, micropipet, stative, thermometer, centrifuge, spectrophotometer [Biochrom Biodrop-DUO], microtube, Thermocycler [Labnet MultiGene Optimax], electrophoretic set [Mupid- Exu], Transilluminator gel documentation [Enduro GDS-1302]. The materials used in this study were taken from meat grinding facilities. Samples were taken at 11 meat grinding locations in PDPS Surabaya that covered the South, North, Central, West and East Surabaya areas. The meat grinding location is actively operating. Sampling was done using a random sampling method. The materials used for this study were, Wizard KIT Promega ${ }^{\circledR}$, ethanol 70\%, isopropanol, Go Taq Green Master Mix ${ }^{\circledR}$, TAE buffer, BenchTop DNA ladder 100 bp, loading dye, free nuclease water, Diamond nulcei acid, negative control sample, pig primer, agarose, tissue.

\subsection{Sample preparation}

Pig samples used as positive control that came from the pig intestine, fat, liver, blood, and meat from traditional markets in Surabaya. This sample was chosen as an analogy to a sample in a meat grinding that we don't know where it came from. The sample was washed and then weighed $50 \mathrm{mg}$ and put into a micro tube for DNA isolation.

\subsection{Extraction of DNA}

DNA extraction was carried out using the protocol according to the Promega Kit. As much as 50 mg of sample was added $600 \mu \mathrm{L}$ Nuclei Lysis Solution, vortex in 10 seconds, and incubated $65^{\circ} \mathrm{C}$ for 30 minutes. Added $3 \mu \mathrm{l}$ RNAse Solution, vortex in 10 seconds, incubated $37^{\circ} \mathrm{C}-30$ minutes, cooled at room temperature 15 minutes, added $200 \mu \mathrm{L}$ PPS, vortex in 10 seconds, freezed in 5 minutes, and centrifuged $15000 \mathrm{x}$ g for 4 minutes. Tube containing $600 \mu \mathrm{L}$ of isopropanol is inserted supernatant, inverted, then centrifuged $15000 \mathrm{x}$ g for 1 minute, supernatant removed, $600 \mu \mathrm{L} 70 \%$ ethanol added, dried at room temperature, $100 \mathrm{~mL}$ of DNA rehydration solution added. Measurement of DNA concentrations using a spectrophotometer Thermo Scientific Biodrop. Samples were dropped on the sensor as much as $1 \mu \mathrm{L}$ alternately starting with dripping DNA rehydration as a blank solution of $3 \mu \mathrm{L}$

\subsection{PCR Amplification}

PCR analysis was performed using the GoTaq Green Master Mix Amplification Kit. The reaction components used were $25 \mu \mathrm{L}$, consisting of $2.5 \mu \mathrm{L}$ DNA samples, Primer F $1 \mu \mathrm{L}, 1 \mu \mathrm{L}$ Primers R, 12.5 $\mu \mathrm{L}$ GoTaq Green, and $8 \mu \mathrm{L}$ Nuclease Free Water. The amplification process was carried out under predenaturation conditions at a temperature of $95^{\circ} \mathrm{C}$ for 5 minutes, denaturation of $95^{\circ} \mathrm{C}-45$ seconds, 
annealing $60^{\circ} \mathrm{C}-30$ seconds, extension $72^{\circ} \mathrm{C}-40$ seconds, and postextension $72^{\circ} \mathrm{C}-5$ minutes. The primer used is pig $c y t$ - $b$ gene with the following sequence (Table 1):

Table 1. Primer Sequences

\begin{tabular}{clc}
\hline Name & \multicolumn{1}{c}{ Oligonucleotide } & Ampli-con \\
\hline$c y t b$ & Primer F 5' CTACGGGTCTGTTCCGTTGG 3' & \multirow{2}{*}{$149 \mathrm{bp}$} \\
& Primer R 5' ATGAAACATTGGAGTAGTCCTACTATTTACC & \\
\hline
\end{tabular}

\subsection{Electrophoresis and Visualization of PCR Products}

PCR product was visualized by $2 \%$ agarose gel electrophoresis in a TAE buffer solution. Agarose gel was placed in an electrophoresis device containing a 1x TAE buffer solution, ladder was inserted into the first well as much as $5 \mu \mathrm{L}$ and followed by PCR samples in the next well as much as $5 \mu \mathrm{L}$ each. The electrophoresis process was carried out at 50 volts for 70 minutes. Visualization of PCR products using gel documentation system.

\section{Results and Discussion}

After DNA extraction is carried out on the sample, DNA concentration measure using a Thermo Scientific Biodrop spectrophotometer, the following results are obtained (Table 2):

Table 2. Code and DNA concentration of each sample

\begin{tabular}{ccccc}
\hline No. & Code 1 & Code 2 & Location & Concentration $(\mu \mathrm{g} / \mathrm{ml})$ \\
\hline 1 & A1 & B1 & Pasar Wonokromo & 6,373 \\
2 & A2 & B2 & Pasar Mangga Dua & 1,400 \\
3 & A3 & B3 & Pasar Ampel & 0,197 \\
4 & A4 & B4 & Pasar Wadung Asri & 1,312 \\
5 & A5 & B5 & Pasar Simo & 0,270 \\
6 & A6 & B6 & Pasar Tembok & 2,783 \\
7 & A7.1 & B7.1 & Pasar Simo (1) & 2,140 \\
8 & A7.2 & B7.2 & Pasar Simo (2) & 2,093 \\
9 & A8.1 & B8.1 & Pasar Pucang (1) & 0,497 \\
10 & A8.2 & B8.2 & Pasar Pucang (2) & 0,395 \\
11 & A9 & B9 & Pasar Simo Gunung & 0,158 \\
\hline
\end{tabular}

Note: Code 1 and Code 2 are show replication in PCR process.

Spectrophotometry results showed that the highest DNA concentration was shown by sample 1, while the lowest concentration was shown by sample 11. Samples with high concentrations showed good results and matched with promega KIT. The concentration results obtained are feasible to proceed towards the PCR process.

The results of Geldoc visualization showed that no band DNA appeared at the primer threshold of the $c y t b$ gene of pig DNA on \pm 149 bp. So the results of the twelve samples show negative as seen in Figure 1 below.

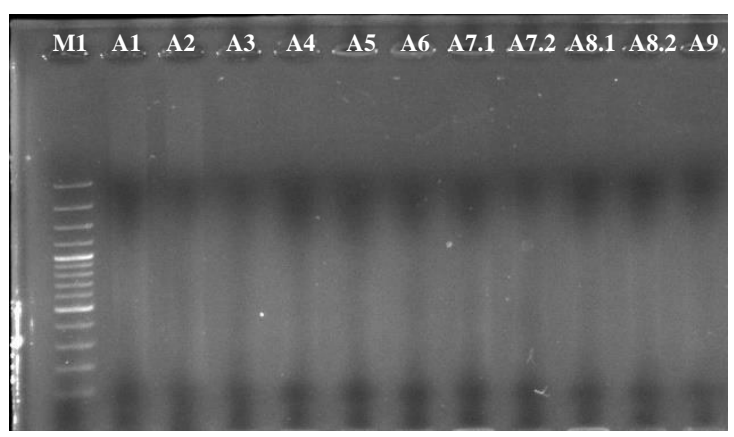

$(1.1)$ 


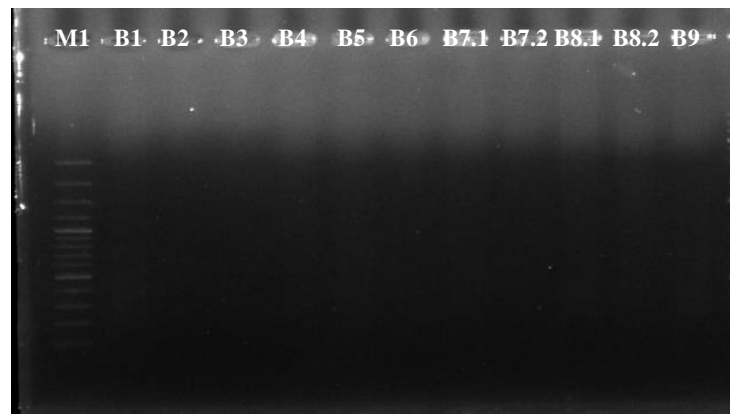

(1.2)

Figure 1. Visualization of DNA amplification of meat grinding samples through geldoc (1.1), results on first PCR replication (1.2), results on second PCR replication

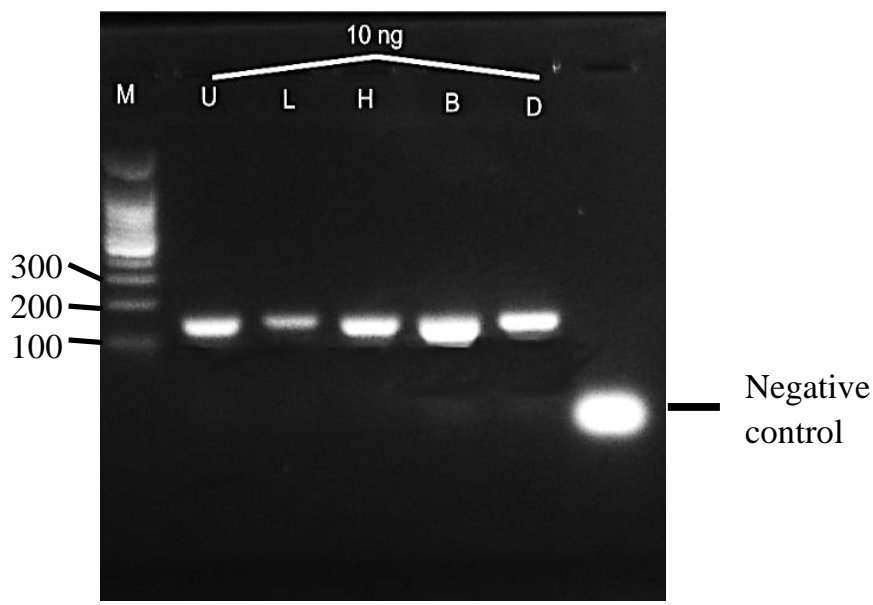

Figure 2. Visualization results of a positive control sample and a negative control sample.

Description: M: Marker or Ladder 100bp; U: Pig intestine; L: Pig fat; H: Pig liver; B: Pork; D: Pig blood. Negative control: Beef.

Pig DNA detection test on PD Pasar Surya of Surabaya meat grinding samples using PCR begins with DNA extraction. DNA extraction of the samples was carried out using the standard method of KIT Promega that had been modified for pig contaminated products, continued by isolating DNA sample, spectrophotometry, PCR amplification, Electrophoresis, and Visualization of PCR results. The DNA of the isolated genome was determined by measuring DNA concentration using a Thermo Scientific Biodrop spectrophotometer. The results of the concentration data can be seen in Table 2 .

DNA obtained was amplified by PCR method and using $c y t b$ primers. According to Dooley, Paine, Garrett, \& Brown (2004), the $c y t b$ primer is a universal pig primer that amplifies \pm 149 bp $c y t b$ genes. The sequences of forward primers and reverse primers can be seen in Table 1. Replication needs to be done at the PCR process to ensure that the PCR process is running correctly at each stage. In this research, no replication was carried out in the extraction process because the DNA concentration obtained from each sample was considered sufficient to carry out the PCR process.

Peccia \& Hernandez (2006) revealed that basically the principle of DNA isolation is to lyse cells and purify nucleic acids (DNA). Lysis is the destruction of walls and releasing DNA that can be done physically or chemically. DNA purification is the process of separating DNA from cell lysates (proteins, carbohydrates, lipids) and other contaminants. One of the factors that influences the success of DNA isolation at the annealing stage, because if the temperature is too high it will cause the failure of the amplification process while if the temperature is too low then the DNA formed has low specificity (Muladno, 2010).

The PCR reaction process consists of 3 main stages: denaturation, annealing, and elongation (Extension). The three stages will occur at a temperature that has been set. In the first stage, denaturation of the main DNA fragment will occur. The denaturation temperature carried out in the study was $95^{\circ} \mathrm{C}$. The single strand of denatured DNA will then undergo a process of annealing by a forward or reverse primer at $60^{\circ} \mathrm{C}$. The last process is the lengthening of the DNA chain at a temperature of $72^{\circ} \mathrm{C}$ in 
accordance with the target base length that has been determined. The DNA product formed in the first amplification will become a template in the next cycle.

The results of the visualization of 11 samples in this study showed that DNA was successfully isolated. The existence of DNA in this study is known by analyzing the appearance of electrophoretic visualization of agarose gel shown in Figure 1. Visualization of DNA from PCR reaction was carried out on agarose gel $2 \%$. The positive control used in this test is the primary gene cyt b DNA from pure non-processed pig derivative samples. Figures 1 and 2 show that all samples are negative, this is indicated by the absence of DNA bands at the primer threshold of the cyt $b$ pig DNA gene of $\pm 149 \mathrm{bp}$. Base pairs are a measure of the length of bands of DNA on an international scale. $1 \mathrm{bp}$ is the same as $3.4 \AA$ (340pm) (Pahlevi, 2013). These negative results indicate that no pork contamination was found in the meat sample obtained from the PD Pasar Surya meat grinding in Surabaya. The positive control showed a DNA band of $\pm 149 \mathrm{bp}$. While the negative control did not show the DNA band, only the residual primer was present at the bottom of the electrophoresis gel when visualized.

Although in this study no pig DNA contaminants were found in meat grinding samples, it is necessary to carry out further tests such as Real-Time PCR to determine whether the sample really does not contain pig. A number of published works have reported the advantages of using Real Time-PCR compared with conventional PCR for species identification (Septiani, 2019). Septiani (2019) added the ability to detect very small size products, since it eliminates the need for gel visualization, the reduced risks for crossover contamination, as reaction are kept confined during amplification and analysis and capability for large scale processing and high automated throughput. Preventive measures are needed by The Government to immediately regulate halal guarantees for public facilities such as meat grinding.

\section{Conclusion}

Meat grinding samples taken at 11 points of PD Pasar Surya Surabaya are not found (negative) the presence of pig contamination based on Polymerase Chain Reaction (PCR) Test. This is proven by the absence of DNA bands encoding the pig $c y t b$ gene by $\pm 149 \mathrm{bp}$. However, preventive measures are needed by The Government to immediately regulate halal guarantees for public facilities such as meat grinding locations.

\section{Acknowledgement}

Our gratitudes go to Lembaga Penelitian dan Pengabdian Masyarakat (LPPM) for 2017 Research Funding, Genetics and Tissue Culture Laboratory-Integrated Laboratory of UIN Sunan Ampel Surabaya for supporting research facilities.

\section{References}

Baihaqi, M., Rachmawati, Y., Rokhim, S., Munir, M., \& Hamidah, L. (2019). Real Time PCR Assays for Detection and Quantification of Porcine DNA in Meat Milling Samples. ICOST: EAI Proceeding, 1-7. https://doi.org/10.4108/eai.2-5-2019.2284634

Dooley, J. J., Paine, K. E., Garrett, S. D., \& Brown, H. M. (2004). Detection of Meat Species using TaqMan Real-time PCR Assays. Meat Science, 68(3), 431-438. https://doi.org/https://doi.org/10.1016/j.meatsci.2004.04.010

Fatchiyah, A. E. L., Widyarti, S., \& Rahayu, S. (2011). Biologi Molekular Prinsip Dasar Analisis. Jakarta: Erlangga.

Jain, S., Brahmbhatt, M. N., Rank, D. N., Joshi, C., \& Solanki, J. V. (2007). Use of Cytochrome b Gene Variability in Detecting Meat Species by Multiplex PCR Assay. Indian Journal of Animal Sciences, 77(9), 880-881.

Muladno. (2010). Teknologi Rekayasa Genetik (2nd ed.). Bogor: IPB Press.

Pahlevi, M. R. (2013). Deteksi Cemaran Babi dengan Porcine Detection Kits Penggilingan Bakso di Kota Bogor. Institut Pertanian Bogor.

Peccia, J., \& Hernandez, M. (2006). Incorporating Polymerase Chain Reaction-Based Identification, Population Characterization, and Quantification of Microorganisms Into Aerosol Science: A Review. Atmospheric Environment, 40, 3941-3961.

Putra, S. T. (1997). Biologi Molekuler Kedokteran. Surabaya: Airlangga University Press.

Rachmawati, Y., \& Daryono, B. S. (2014). Karakter Fenotip dan Molekular Melon (Cucumis melo L." Tacapa”) pada Media Tanam Tanah Karst. Yogyakarta: Universitas Gadjah Mada. 
Rachmawati, Y., Rokhim, S., Munir, M., \& Agustina, E. (2018). Deteksi Kontaminan Fragmen DNA Pengkode cyt b Babi Pada Sampel SOFTGELLCANDY Tak Berlabel Halal. Indonesia Journal of Halal, 1(1), 25. https://doi.org/10.14710/halal.v1i1.3115

Septiani, T. (2019). Detection of Porcine DNA in Processed Beef Products Using Real Time Polymerase Chain Reaction. Indonesian Journal of Halal Research, 1(2), 31-34. https://doi.org/10.15575/ijhar.v1i2.5601

Widayanti, R., Solihin, D., Sajuthi, D., \& Perwitasari, R. (2006). Kajian penanda genetik gen cytochrome B pada Tarsius sp. Jurnal Sain Veteriner, 24(1), 1-8.

Yusuf, Z. K. (2010). Polymerase Chain Reaction (PCR). Saintek, 5(6), 1-6. https://doi.org/10.11501/3061795

(C) 2020 by the authors. Submitted for possible open access publication under the terms and conditions of the Creative Commons Attribution (CC BY SA) license (https://creativecommons.org/licenses/by-sa/4.0/). 